\title{
Colonization of the West: preliminary analysis and long-term prospects
}

\author{
Vladimir Jakovlev ${ }^{1 *}$, Petr Perlin ${ }^{1}$ \\ ${ }^{1}$ Herzen University, Institute of Regional Studies, St. Petersburg, Russia
}

\begin{abstract}
More than a hundred years ago, the World powers have started to turn China into a "subcolony", and now the world faces a reversed process. China expands over the world, not with the use of military force, but adopting economic tools to make other countries heavily depended or indebted to China. The modern geopolitical situation requires new solutions, and it seems relevant to develop them basing not only on the present short-term concerns, but also on the legacy of the past era. There is a need for detailed understanding of the phenomenon of "reverse colonization" in order to deploy effective measures in order to ensure independent development of the economic and cultural situation in the non-Chinese world.
\end{abstract}

\section{Introduction}

In the second half of the 19th century, the European powers forced open the shell of China's self-isolation. As a result of the so-called "Opium wars" the economy, culture and lifestyle of the huge empire have drastically changed. The line of events of this process is well studied and described $[1,2,3]$, new studies can only add colourful nuances to the overall picture of what happened. The result of this process was that the economic game in the enormous market of the gigantic country began to be played according to the rules that were determined from outside its borders. Now is the time to face the consequences of the events of almost two hundred years ago. China - not as forcefully as Western countries did then - penetrates the markets and even ways of life of the rest of the world, introducing its own rules of the game, and now to many people in the West, especially in Europe, this penetration appears to be an invasion. Recently, this expansionary policy of China has been formulated in the highly publicized concept of the Belt and Road Initiative [6].

Despite the seeming symmetry of these two processes (in the 19th century, the West was striving to get to the markets of China, in the 21st century China is expanding to the West, and the driving force behind both processes was and is the desire to expand living space and obtain material benefits, gain influence on world processes and political weight), there are serious differences in approaches due to the mentality, traditions and historical characteristics of the development of expansionists and targets of expansion.

\section{Results and discussion}

Historically, the West mostly acted in a rather straightforward manner, with military force being the main instrument of the expansion of the Western powers. In the case of China, the specific features of the expansionist (read - "colonial") policies of the powers were caused not only by economic reasons (China was a source of goods in demand in Western countries - tea, silk, porcelain and other exotic products, as well as, potentially, labour), but also political rivalry between Western countries seeking to take control of at least part of the vast territory of China. When exclusive control was not possible, they came to agreements on the division of occupation zones, spheres of influence, on commercial preferences, etc. As a result, by the end of the 19th century China turned, using the words of Sun Yat-sen, into a hypokolonie (次殖民地) [7], that is, a country that obeys not one, but several states at once.

China once again demonstrates the characteristic feature of its culture - the ability and willingness to absorb external impulses and use foreign phenomena to its own advantage. China's penetration into the West is a gradual, non-violent process. Nevertheless, in this process one can already see features that make it akin to colonial expansion [8]. German historian J. Osterhammel defines colonialism as the relationship between a local majority and a minority of foreign invaders [9]. The main decisions affecting the life of the population of the colony are taken and implemented by the local administration in the interests of the metropolis; no compromise with the cultural characteristics of the local population; the confidence of the colonialists in their own superiority and the supreme right to govern the territory. In accordance with the presence of these features, we define the actions of Chinese actors in some countries of Southeast Asia, Africa and Europe (primarily in the Balkans) as colonial [6].

Li Hongzhan, this "Bismark of the East" can be taken as an example of one of the first scouts of this expansionist army. In the Chinese history of 19th

nii.region@mail.ru 
century there is hardly another character whose contemporaries and descendants would be so different in assessing his activities and personality. Li Hongzhang, who shaped the internal and foreign policy of the Qing Empire for about 30 years, still remains one of the most controversial figures of the end of the century before last - a century so rich in events and personalities that radically changed the fate of China.

In the memoirs of Sergei Witte, the Minister of Finance of Russia in 1892-1903, who met with him several times, we find the following assessment of $\mathrm{Li}$ Hongzhang's personality and the prominent place he occupied in the political life of China and in the international arena:

"Regarding Li-Hun-Chan, I must say that during my career I have met a lot of statesmen, the names of some of them will forever remain in history, and among them I put Li-Hun-Chan on a high pedestal: he was, indeed, an outstanding statesman, but, of course, he was a Chinese with no European education, though with an enormous Chinese education - and most importantly, with outstanding sober mind and common sense.

It is not without reason that he was of such tremendous importance in the history of China and in the government of China; in fact, Li-Hun-Chan ruled the Chinese Empire" [10].

In 1896, this viceroy of the Chinese province of Zhili and most powerful dignitary of China at that time made a several month voyage across Russia, Western Europe and the United States, and information about this trip became known to relatively wide reading circles in China itself.

Since the Sung times, Chinese officials were required to submit reports on their diplomatic trips to the court [11] - such a document was a cross between a diary, memoirs and an espionage report. However, in the case of Li Hongzhang, due to the uniqueness of the voyage itself and (the first trip of an official of this rank to almost all significant Western countries) and the tasks that he pursued (in fact, one of them was defining the style of communication with Western partners for the future), the materials about this trip of his became something more than a trip report. First of all, Li Hongzhang's report turned out to be addressed to a much wider audience than the emperor's bureaucracy. Second, quite in the spirit of the Chinese avoidance of straightforwardness and concealment of true intentions, it acquired the features of a myth. Among the evidence of this "trip to the West" we may mention two most interesting documents (both were not created by Lee himself) [12]:

- a report compiled by Cai Erkang and John Allen Young based not only on diaries of Li himself and his secretaries, but on excerpts from Western newspapers: $A$ record of the successive embassies of inquiry of $\mathrm{Li}$ Hongzhang to Europe and America [13] (we were unable to find a translation into English or Russian); and

- an American-made fake memoirs published in 1913 by William Francis Mannix [14].

The first source published in China brought the account of the long trip and meetings of a Chinese nobleman with the heads of the most powerful powers in the world (for the first time in history on their grounds) to the general Chinese public.

The second, completely fabricated by the American adventurer Mannix, presented to the wider Western public the image of an exotic Chinese ruler ( $\mathrm{Li}$ Hongzhang in the West was seriously talked about as the only person in the world with his own private army). (It's hard to believe, but the Memoirs are still being referred to as an authentic source, so this is a high-level falsification - quite, by the way, in the tradition of famous Chinese counterfeiters.)

It is worth mentioning that the Introduction to the Memoirs was written by John Foster (who had met Li Hongzhan personally before), an American diplomat, military officer, a lawyer and journalist, and the grandfather of Allan Dulles, the first civilian Director of Central Intelligence. This person, who does not cause any doubts in his objectivity and sincerity, described his impressions of Li Hongzhang as follows.

"Li Hung Chang was not only the greatest man the Chinese race has produced in modem times, but, in a combination of qualities, the most unique personality of the past century among all the nations of the world. He was distinguished as a man of letters; as a soldier in important campaigns he rendered valuable services to his country. As a statesman for thirty years he maintained a recognized preeminence over his countrymen in the oldest and most populous nation of the earth; and as a diplomat his achievements entitle him to a front rank in the international relations of all history" $[14$, p.xi].

William Mannix, like any professional deceiver, felt well what was supposed to capture the interest of a Western reader, and painted an image of exotic, mysterious and attractive - no, not an official, but China itself. These characteristics were what largely had determined the interest of the Western public in everything Chinese (Far East) in the future. And in this sense, he has added more ammunition to the general program of relations with the West tacitly adopted by China in the century before last and successfully implemented in this century: "beads and trinkets in exchange for high technology".

Western dignitaries who met with the Li Hongzhang clearly understood the pragmatic nature of his relations with the West. There was no illusion in this respect. There could be no partnership, equal relations. China could not interest the West with anything, except for things that the West was already set to get by coercion.

(Resistance to force by force is not for China. Thus, in the first Opium War, 40 ships and 4,000 British soldiers defeated China, which possessed an 880,000strong army - although due to the disorderly organization of command and control, "only" 90,000 Chinese servicemen participated in the conflict.)

So Li laid down the following mode of relations with Western partners: 1) playing on contradictions between Western countries; 2) promises of large orders at factories (by the way, during that visit, Krupp never received the huge military order from China which he was hoping for); 3) working to lift restrictions on the movement / migration of Chinese to the West (America), 
and at the same time, keeping China far from being so open for Westerners.

In the late 19 th - early 20th century, another wave of sinophilia (after the sixteenth and most of the seventeenth century [15]) engulfed the West, which we also owe, among other things, to Li Hongzhang. China started massive supplies of more or less exotic products, exotic food and exotic exercises ("martial arts). That is, over time China was able to find something (those same "beads and trinkets") to wave in the face of the West, at the same time reaching into its pockets, just like professional pickpockets do with tourists on the streets of big cities.

Over the next century and a half, exotic Chinese culture successfully secured the place of the Chinese in the Western world. Philosophy, cuisine, visual arts and martial arts. The export product, of course, was often inferior, or even had nothing to do with products for home consumption (to this day it is difficult, if not impossible, to find a Chinese restaurant outside China with food comparable in taste to what you can taste in China itself. It is the same with the rest of exported Chinese things.)

Chinese merchants, travelling to the most remote places around the world, bring the local population not only cheap clothes and shoes, but also Chinese amulets, frogs with coins in their mouths and pot-bellied smiling dummies; and all this helps maintaining the image of a mysterious but cheerful, simple-minded and benevolent nation. Only in a relatively recent times, a series of scandals related to industrial espionage in favour of Chinese companies broke out. Numerous reports appeared in the press detailing large-scale infrastructure projects in different parts of the world, thanks to which entire countries fell into debt bondage to Chinese financial institutions. All this finally forced the Western world to take a fresh look at the former victim of colonial expansion, who imperceptibly changed roles with the former aggressor [16].

When we mention "expansion", we are talking not only and not so much about the physical presence of Chinese citizens, about enclaves (so-called Chinatowns), where immigrants from China live compactly and where the Chinese language, their way of life, and business prevail. Penetration is primarily economic, but along with it there is also an ideological indoctrination of local residents in the best traditions of "soft power" with the participation of language schools (Confucius Institute), medical, general health and cultural centers. This is a manifestation of "soft power" in its pure form; that is, focused primarily not on economic interests, but on the interest of target audiences in the culture and history of China.

Professor Lu Gang (East China Normal University), who has been dealing with BRI issues since 2016, writes in his article named Geopolitical Clash of Civilizations in the Balkans and Market Consolidation in the Framework of the Belt and Road Initiative: “... the Belt and Road Initiative ... is a great social experiment. It affects not only economics and trade, but also politics, culture and regional civilization [processes]. Historically, the Balkans have been a 'powder barrel' where different cultures clashed, and one of the most important reasons for these clashes was that the geographic location determined the role of the Balkans in cultural fragmentation and the clash of civilizations. As the Belt and Road Initiative moves deeper into the Balkans, the sensitive issues of culture and way of life in the region will certainly be raised. How the Belt and Road Initiative can be avoided and transform Europe's powder barrel into a region of peace and prosperity? This question is truly noteworthy. After the completion of the initial stage of the infrastructure project, it is necessary to shift the focus to the formation of a Balkan market within the framework of the 'One Belt, One Road' initiative, since the market-oriented economic model is more consistent with the mode of production of the region with great untapped potential at this stage of development. China, which has come to the Balkans, in no way starts a new geopolitical game, but wholeheartedly hopes to cooperate with the Balkan countries, as well as with the countries of America and Europe, in order to jointly eliminate the reasons for the clash of civilizations and thereby build a better world " ... [17].

Describing the plan for economic 'tying' of foreign markets aimed at establishing their economic and, ultimately, political dependence on Beijing, Chinese propagandists constantly declare the complete absence of political goals, the harmony of cooperation and common prosperity. The penetration of China into the Balkans (here the nature of this penetration is clearly reminds of colonial conquests) is a relatively new process in the sense that earlier the Chinese aimed (more or less successfully) at neighboring territories (for example, Tibet, Vietnam) that were considered 'temporarily lost'. Now the expansion covers geographically remote regions that have neither a sea nor a land border with China. And for the external justification of such expansion, Chinese propagandists often resort to a discourse that brings together the fate and history of the Chinese people and the people of the country chosen for penetration in the eyes of the audience. As Professor Lu Gang emphasizes in the article mentioned above, “... China and the Balkan region have a similar fate, throughout history [both of them] have been invaded and enslaved by the great world powers; linguistic diversity exists among peoples; they feel mutual affection; rather good contacts have been established between them..." [17].

As before, 'traditional rights' to certain territories are important for China - it is no coincidence that in their materials Chinese authors call Europe "the terminal of the Great Silk Road" [18].

China, which has built up considerable economic potential, can afford flamboyant rhetoric about "common good", "common destiny", "one belt, one road" [19]. And it is not surprising that the liberal West has repeatedly fallen for this bait and took such words at face value. Meanwhile, "appropriating from barbarians" took place both in the form of direct theft of technology and scientific materials by Chinese companies, and in the form of a "brain drain to the East" - from prominent scientists who agreed to work for large sums of money 
for Chinese scientific centres, to a mass of English language teachers that poured into China since the beginning of the 2000s. About five years ago, Western specialists politely but firmly were being asked to leave; in a situation of isolation due to the recent pandemia, this process has accelerated significantly. But, having retreated, this wave of Western experts left a lot of values scattered on the Chinese coast. It is thanks to this policy that science in China is making many landmark breakthroughs in areas requiring gigantic funding. Among them are the mission to Mars, lunar probe "Chang'e-5", manned deep-sea underwater vehicle "Fendouzhe", which dived to a depth of 10909 meters, development of the third-generation nuclear reactor technology "Hualong-1", genetic engineering and biotechnology (the world's first atlas of human cells organism was compiled there), the space program, a powerful research fleet, the most powerful Tianyan radio telescope in Guizhou province, about half of all the world's most powerful supercomputers (including the qubit-based computer Jiuzhang), funding for research in Antarctica, etc.

\section{Conclusion}

Although it is necessary to mention serious problems in the Chinese science (i.e., in the creation of anything new in general, in the Western sense) associated with the specifics of Chinese culture and historical tradition. For millennia, China has developed the ability to copy and imitate, which is still reflected in today's Chinese schooling. European science follows the path of competition between scientific schools, criticism and experiment. Chinese science rather takes creative impulse from outside, adapts it to the local conditions and offers a variety of applications. Historically, it so happened that as early as in the 18th century in China, a stable political and economic structure was formed, which significantly reduced the desire for development via generation of new ideas, reduced the number of incentives for the development of new technologies, in particular, production. In addition, the Chinese intellectual elite in general traditionally took little interest in science per se, and centralized structure of power over a vast territory reduced one of the driving forces of technological progress - regional competition. All this gives hope that in the future world, which has adopted the new Chinese order; there will be room for the Western way of life, thinking, scientific and business practice. However, letting things go by themselves seems short-sighted. Just as it happens with promising markets, which the Chinese, in their thirst for quick profit, are turning into a trampled wasteland, it can also happen with the world order as a whole. In an effort to impose the path of "common destiny" on the whole world, China is capable, albeit inadvertently, of destroying everything that for several thousand years has given Western civilization the impetus for development.

The EU has only recently started to realize the danger of the Chinese expansion to the Western Balkan states. At the beginning of 2018, the European Commission adopted a new strategy, in which the expansion of cooperation with the region is called a "geostrategic investment". The EU has launched a series of projects in competition with China. And the results of this opposition are becoming visible. Some EU countries bordering the region and economically close to the countries of the Western Balkans begin to denounce previously concluded agreements. For example, Romania decides not to allow Huawei to deploy 5G networks in the country due to the fact that the company does not meet the security criteria (companies controlled by foreign governments with an opaque ownership structure, in the past violating corporate ethics and companies from countries with no judicial system independent of the state). In the same country, plans to build a nuclear reactor by the Chinese were abandoned. There is a possibility that this process will continue.

In this situation, non-Chinese countries need to clearly understand not only goals and objectives of China's expansionist policy, which is steadily striving to expand its influence throughout the world, but also the prospects for the world in the event of successful implementation of these goals and objectives (which will have disastrous consequences for the way of life, economy and cultural life of so far non-Chinese countries), to realize the need to oppose their own (common or multiple national) programs for the protection of values and cultural order.

\section{References}

1. J. Fairbank. The Chinese world order. (Cambridge, 1968)

2. P. Fay. The Opium War, 1840-1842: barbarians in the Celestial Empire in the early part of the nineteenth century and the war by which they forced her gates ajar (Univ. of North Carolina Press, 1975)

3. 《鸦片战争》 1972 年上海人民出版社

4. J. Lovell. The Opium War: Drugs, Dreams, and the Making of Modern China (2011).

5. M. Elvin. The pattern of the Chinese past. (Stanford University Press, 1973)

6. P. Perlin, V. Yakovlev. The Belt and Road Initiative: Chinese Expansion in the Balkans, Problems and Prospects // IV Gottlieb Readings Oriental and Regional Studies of the Asia-Pacific Region in the Transdisciplinary Context Knowledge. Materials of the International Scientific Conference Irkutsk, December 7-9, pp. 369 - 377 (2020)

7. 孙中山 三民主义 中国长安出版社 Sun Zhongshan Sanmin zhuyi Zhongguo Changan chubanshe 2011 ISBN: 9787510703973 Three Principles of the People

8. D. Fieldhouse. Colonialism 1870-1945: An Introduction. (L., 1981)

9. J. Osterhammel. Colonialism: A Theoretical Overview. (Princeton, N.J.: Markus Wiener Publishers, 1997) 
10. The Memoirs of Count Witte. (Moscow, 1960)

11. I. Alimov. Bureaucracy in Motion: Chinese Travel Diaries of the X-XIII centuries. (I) // MONGOLICA. XXIV. No. 3 (2021)

12. P. Perlin. Western European, American and Chinese sources about Li Hongzhang's round-the-world voyage: Europe and America // Encyclopedic Practice: Materials and Research Collection of scientific articles and documents. Encyclopedic Department of the Institute for Philological Research, St. Petersburg State University. St. Petersburg, Scriptorium (2017)

13. 李鸿章历聘欧美记- 蔡尔康, 林乐知編译; 张英宇 点; 张玄浩校 - 湖南人民出版社 1982

14. Li Hung Chang. Memoirs of Li Hung Chang; ed. By W. F. Mannix (1913)

15. A. Millar. The Jesuits as knowledge brokers between Europe and China (1582-1773): shaping European views of the Middle Kingdom. Economic History
Working Papers (105/07). Dept. of Economic History, London School of Economics and Political Science, London, UK. (2007)

16. Munich Security Report 2019 The Great Puzzle: Who Will Pick Up the Pieces? https://espas.secure.europarl.europa.eu/orbis/sites/def ault/files/generated/document/en/MunichSecurityRep ort2019.pdf (accessed on 12.09.2021).

17. 陆钢. 巴尔干地缘文明断层与“一带一路”市场整 合《社会科学》2020 年第 1 期 - URL: http://sass.cn/109006/57173.aspx (accessed on: 09.09.2021).

18. Yiwei, W. China and Europe: BRI and the $17+1$ Initiative, Valdai Discussion Club 2020 URL: https://valdaiclub.com/a/highlights/china-and-europebri-and-the-17-1-initiative/ (accessed on: 15.09.2021).

19. 王义桅，《高质量共建“一带一路”的突破口》 《经 济日报》2021年 4 月 21 日 10 版 